\title{
Effect of manipulating progesterone before timed artificial insemination on reproductive and endocrine outcomes in high-producing multiparous Holstein cows
}

\author{
P. D. Carvalho, V. G. Santos, H. P. Fricke, L. L. Hernandez, and P. M. Fricke* \\ Department of Dairy Science, University of Wisconsin-Madison, Madison 53706
}

\begin{abstract}
Our objective was to evaluate the effect of manipulating progesterone (P4) concentrations before timed artificial insemination (TAI) on reproductive and endocrine outcomes in high-producing Holstein cows. Multiparous lactating Holstein cows $(\mathrm{n}=80)$ were synchronized for first TAI using a Double-Ovsynch protocol and were randomly assigned to receive $25 \mathrm{mg}$ of $\mathrm{PGF}_{2 \alpha}$ $1 \mathrm{~d}$ after the first GnRH treatment of the BreedingOvsynch protocol that included a once-used $\mathrm{P} 4$ insert (low-P4 group) or to receive 2 new P4 inserts during the Breeding-Ovsynch protocol (high-P4 group). Blood samples were collected thrice weekly from -10 to $32 \mathrm{~d}$ relative to TAI for all cows and from 32 to $67 \mathrm{~d}$ after TAI for pregnant cows and were analyzed for $\mathrm{P} 4$ and pregnancy-specific protein B (PSPB) concentrations. Expression of IFN $\tau$-stimulated gene 15 (ISG15) was assessed in blood leukocytes 18 and $20 \mathrm{~d}$ after TAI. As expected, $\mathrm{P} 4$ concentrations were greater for high-P4 cows than for low-P4 cows from 3 to $8 \mathrm{~d}$ before TAI. Incidence of double ovulation was 3 -fold greater for low-P 4 cows than for high-P 4 cows (33 vs. 10\%), which resulted in more twin pregnancies $32 \mathrm{~d}$ after TAI for low-P4 cows than for high-P4 cows (29 vs. 0\%). Low-P4 cows had larger preovulatory follicles at the last GnRH treatment of the Double-Ovsynch protocol and greater P4 concentrations than high-P4 cows after TAI. Relative expression of ISG15 mRNA 18 and $20 \mathrm{~d}$ after TAI was greater for low-P4 cows than for high-P4 cows and for pregnant cows than for nonpregnant cows. Overall, PSPB concentrations tended to be greater for low-P4 cows than for high-P4 cows, and pregnant cows had greater $\mathrm{P} 4$ concentrations than nonpregnant cows. In summary, cows with low P4 before TAI had increased preovulatory follicle diameter, PSPB concentrations, relative expression of $I S G 15 \mathrm{mRNA} 18$ and $20 \mathrm{~d}$ after
\end{abstract}

Received February 23, 2019.

Accepted April 3, 2019.

*Corresponding author: pmfricke@wisc.edu
TAI, double ovulations, and twinning compared with cows with high P4 before TAI. Increasing P4 before TAI may effectively decrease double ovulation and twinning in high-producing multiparous Holstein cows. Key words: progesterone, double ovulation, twinning, dairy cow

\section{INTRODUCTION}

Modern high-producing dairy cows experience several reproductive problems, including a high incidence of double ovulation (Wiltbank et al., 2000; Lopez et al., 2005a), increased twinning over time (Silva del Río et al., 2007), and increased pregnancy loss (Santos et al., 2004; Wiltbank et al., 2016). A possible physiologic mechanism that could explain these problems is that high-producing dairy cows experience increased hepatic metabolism of progesterone (P4) due to high feed intake, resulting in decreased circulating $\mathrm{P} 4$ concentrations (Sangsritavong et al., 2002; Vasconcelos et al., 2003). Circulating P4 concentrations in dairy cows at the onset of a fertility protocol have profound effects on fertility to timed AI (TAI) in which cows with low P4 at the first $\mathrm{GnRH}$ treatment or at the $\mathrm{PGF}_{2 \alpha}$ treatment of an Ovsynch protocol have lower fertility than cows with high P4 (Fricke et al., 2003; Bisinotto et al., 2010; Carvalho et al., 2014). More recently, high-producing Holstein cows manipulated to have low P4 concentrations at the first GnRH treatment of an Ovsynch protocol that included a second $\mathrm{PGF}_{2 \alpha}$ treatment given $24 \mathrm{~h}$ after the first to complete luteal regression had a dramatically increased incidence of double ovulation and subsequent pregnancy loss (Martins et al., 2018). To further complicate matters, cows with double ovulations initially have increased fertility to TAI compared with cows with single ovulations (Fricke and Wiltbank, 1999), but cows that conceive twins, particularly unilateral twins, have a 3 -fold increase in subsequent pregnancy losses compared with cows that conceive singletons (López-Gatius and Hunter, 2005; Silva del Río et al., 2009). 
With these effects of $\mathrm{P} 4$ on reproduction in mind, an experiment was conducted in which primiparous and multiparous Holstein-Friesian cows managed in a seasonal-calving pasture-based dairy system in Ireland were manipulated to have either high or low P4 concentrations during growth of a synchronized follicular wave during an Ovsynch protocol (Fricke et al., 2016). In that experiment, the effect of manipulating $\mathrm{P} 4$ before TAI on early embryo development was assessed by measuring circulating $\mathrm{P} 4,4$ different IFN-stimulated genes (ISG), and plasma pregnancy-associated glycoprotein (PAG) concentrations. Low-P4 cows had larger ovulatory follicles and more $\mathrm{P} 4$ after TAI than high-P4 cows; however, this effect was manifested primarily for a subgroup of low-P4 cows that expressed estrus approximately $16 \mathrm{~h}$ before TAI, likely due to the low $\mathrm{P} 4$ concentrations near the end of the protocol as a consequence of the low-P4 treatment. In contrast to the stated hypothesis in that study, there was no effect of treatment on early embryo development based on plasma PAG concentrations and pregnancy outcomes based on transrectal ultrasonography or on the incidence of double ovulation, twinning, or pregnancy loss (Fricke et al., 2016). We speculated that Holstein-Friesian cows managed in a seasonal-calving pasture-based system with moderate milk production (i.e., $<25 \mathrm{~kg} / \mathrm{d}$ near peak production) may not present problems associated with hepatic P4 metabolism similar to high-producing Holsteins housed in confinement-based systems (Fricke et al., 2016).

The objective of this experiment, therefore, was to use an experimental model similar to that used by Fricke et al. (2016) to hormonally manipulate highproducing Holstein cows typical of confinement-based dairy systems in North America into either a high-P4 or a low-P4 environment during growth of a synchronized follicular wave during an Ovsynch protocol to assess the effect of P4 before TAI on the incidence of double ovulation and twinning as well as on IFN-stimulated gene 15 (ISG15) mRNA expression 18 and $20 \mathrm{~d}$ after TAI and serum pregnancy-specific protein B (PSPB) and P4 concentrations after TAI. Our hypotheses were that cows with low P4 during growth of a synchronized follicular wave would (1) ovulate larger follicles, (2) have increased ISG15 mRNA expression and PSPB concentrations after TAI, and (3) have more double ovulations and twinning than cows with high $\mathrm{P} 4$.

\section{MATERIALS AND METHODS}

All animal handling and experimental procedures were approved by the Animal Care and Use Committee of the College of Agriculture and Life Sciences at the University of Wisconsin-Madison.

\section{Cows, Housing, and Feeding}

This study was conducted at the University of Wisconsin-Madison Emmons Blaine Dairy Cattle Research Center located near Arlington, Wisconsin, from April to October 2017. Lactating Holstein cows $(\mathrm{n}=80)$ were milked twice daily at approximately 12 -h intervals and were fed a TMR once daily consisting of corn and alfalfa silage as forage with corn and soybean mealbased concentrate formulated to meet or exceed the minimum nutritional requirements for high-producing dairy cows (NRC, 2001). Cows were housed in freestall barns bedded with sand and had ad libitum access to feed and water. Only multiparous cows were enrolled in this experiment to minimize variation among cows and to study a uniform group of cows with high milk production without the confounding effects of parity (primiparous vs. multiparous). The rolling herd average was $13,880 \mathrm{~kg}$ and average daily milk production was $41.6 \mathrm{~kg} /$ cow per day with $3.8 \%$ fat and $3.2 \%$ protein for the herd during this experiment.

\section{Treatments}

All cows were submitted to a Double-Ovsynch protocol for first TAI (Figure 1) as described by Souza et al. (2008) and modified by Brusveen et al. (2009). The GnRH $(100 \mu \mathrm{g} /$ dose of gonadorelin hydrochloride, Factrel), $\mathrm{PGF}_{2 \alpha}$ (25 mg/dose of dinoprost tromethamine, Lutalyse), and controlled internal drug release (CIDR) inserts (1.38 g of P4/insert) were manufactured by Zoetis (Madison, NJ). Briefly, cows received the first GnRH treatment of the Pre-Ovsynch portion of the Double-Ovsynch protocol starting at $53 \pm 3$ DIM, followed by treatment with $\mathrm{PGF}_{2 \alpha} 7 \mathrm{~d}$ later and treatment with $\mathrm{GnRH} 72 \mathrm{~h}$ after treatment with $\mathrm{PGF}_{2 \alpha}$. Seven days later, cows began the Breeding-Ovsynch portion of the Double-Ovsynch protocol in which cows received a GnRH treatment $(\mathbf{G 1})$ followed by $2 \mathrm{PGF}_{2 \alpha}$ treatments administered 7 and $8 \mathrm{~d}$ later and the last $\mathrm{GnRH}$ treatment $(\mathbf{G} 2)$ administered $56 \mathrm{~h}$ after the first $\mathrm{PGF}_{2 \alpha}$ treatment followed by TAI 16 to $20 \mathrm{~h}$ after G2. One day after G1, cows were randomly assigned to 1 of 2 treatments: 2 new CIDR inserts for $7 \mathrm{~d}$ (referred to as the high-P4 group; $\mathrm{n}=40$ ) or $25 \mathrm{mg}$ of $\mathrm{PGF}_{2 \alpha}$ and a once-used CIDR insert for $7 \mathrm{~d}$ (referred to as the low$\mathrm{P} 4$ group; $\mathrm{n}=40 ;$ Figure 1 ). To create once-used CIDR inserts, CIDR inserts were inserted into multiparous lactating Holstein cows at G1 of a Double-Ovsynch protocol and were removed at the first $\mathrm{PGF}_{2 \alpha}$ treatment (i.e., $7 \mathrm{~d}$ later) of the Breeding-Ovsynch portion of a Double-Ovsynch protocol. Once-used CIDR inserts were then scrubbed with a mild disinfectant diluted in hot water (Nolvasan Solution, Zoetis, Madison, NJ) 


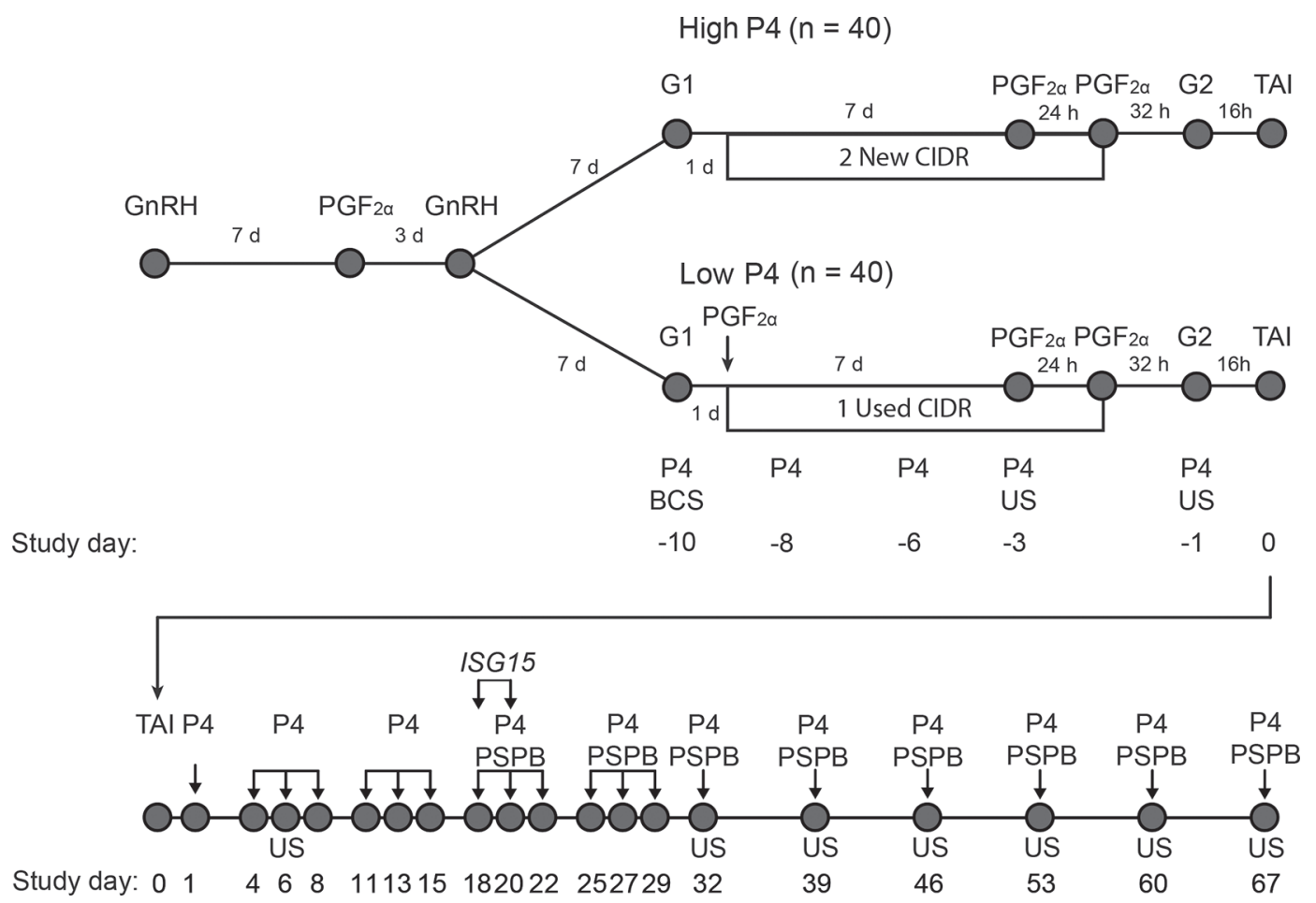

Figure 1. Schematic diagram of the treatment protocols used to manipulate lactating multiparous Holstein cows into a high-progesterone (high-P4) versus a low-progesterone (low-P4) environment before timed AI (TAI) and timing of blood sampling after TAI to assess serum progesterone (P4) concentration, IFN-stimulated gene 15 (ISG15) mRNA expression in blood leukocytes, and serum pregnancy-specific protein B (PSPB) concentration. G1 = first GnRH treatment of the Breeding-Ovsynch portion of the Double-Ovsynch protocol; G2 = last GnRH treatment of the Breeding-Ovsynch portion of the Double-Ovsynch protocol; CIDR = controlled internal drug release; US = ultrasound.

and allowed to air dry. After drying, CIDR inserts were autoclaved and stored in plastic bags in the dark until used in the present experiment. Multiple sires with high genetic merit and proven fertility were used for TAI, and sires were equally balanced between treatments.

\section{Transrectal Ultrasonography}

Number of corpus luteum (CL) was evaluated at the time of the first $\mathrm{PGF}_{2 \alpha}$ treatment of the BreedingOvsynch portion of the Double-Ovsynch protocol (Figure 1) by transrectal ultrasonography using a portable scanner (Ibex Pro, E. I. Medical Imaging, Loveland, $\mathrm{CO}$ ) equipped with a $7.5-\mathrm{MHz}$ linear-array transducer to determine response to the treatment protocols. On the day of G2, number and size of follicles $\geq 10 \mathrm{~mm}$ in diameter were also recorded. Ovulation was confirmed by disappearance of 1 (single ovulation) or 2 (double ovulation) follicles $\geq 10 \mathrm{~mm}$ in diameter and appearance of 1 or more CL in the same locations as the preovulatory follicles $6 \mathrm{~d}$ after TAI (Figure 1).

Pregnancy diagnosis and measurement of embryonic crown-rump length were performed using a portable scanner (Ibex Pro, E. I. Medical Imaging) equipped with a $7.5-\mathrm{MHz}$ linear-array transducer. A positive pregnancy diagnosis was based on visualization of a CL on the ovary ipsilateral to the uterine horn containing an embryo with a heartbeat. Pregnancy status for cows diagnosed pregnant $32 \mathrm{~d}$ after TAI was reconfirmed weekly until $67 \mathrm{~d}$ after TAI. Any cow diagnosed pregnant and subsequently diagnosed not pregnant at a pregnancy confirmation was considered to have undergone pregnancy loss. Images were frozen when the crown-rump length was determined visually to be at its maximal size, and the length was then measured using the built-in digital calipers of the ultrasound machine.

\section{Blood Sample Collection}

Blood samples to assess P4 and PSPB concentrations were collected via puncture of the median caudal veins or arteries into 8-mL evacuated serum collection tubes (Vacuette, Greiner Bio-One North America Inc., Monroe, NC) thrice weekly beginning at G1 (i.e., immediately before GnRH treatment) until 32 d after TAI for all cows and then weekly until $67 \mathrm{~d}$ for cows diagnosed pregnant $32 \mathrm{~d}$ after TAI (Figure 1). Blood samples were immediately placed on ice after collection 
and were centrifuged $\left(1,600 \times g, 4^{\circ} \mathrm{C}\right)$ for 20 min within $2 \mathrm{~h}$. Serum was harvested and stored at $-20^{\circ} \mathrm{C}$ until assayed for P4 and PSPB. Blood samples $(3 \mathrm{~mL})$ for analysis of ISG15 mRNA expression were collected 4, 18 , and $20 \mathrm{~d}$ after TAI from the coccygeal vessels into Tempus Blood RNA tubes containing $6 \mathrm{~mL}$ of RNA stabilization solution (Applied Biosystems, Foster City, CA). Tubes were shaken vigorously by hand for 20 s immediately after collection, and whole blood was stored in the Tempus tubes at $-20^{\circ} \mathrm{C}$ until the mRNA isolation procedure.

\section{Analysis of P4 and PSPB}

Serum P4 concentrations were determined using a solid-phase, no-extraction RIA (MP Biomedicals, Solon, $\mathrm{OH})$. The average sensitivity for the 3 assays was 0.027 $\mathrm{ng} / \mathrm{mL}$. The average intra-assay coefficient of variation $(\mathbf{C V})$ was $5.6 \%$, and the interassay $\mathrm{CV}$ was $6.9 \%$ based on a quality control sample $(2.50 \mathrm{ng} / \mathrm{mL}$ of $\mathrm{P} 4)$ that was replicated within each $\mathrm{P} 4$ assay. Concentrations of PSPB were determined using a quantitative ELISA (Biopryn, BioTracking LLC, Moscow, ID). The average intra-assay CV was $5.3 \%$, and the interassay $\mathrm{CV}$ was $7.4 \%$ based on a quality control sample $(0.9 \mathrm{ng} / \mathrm{mL}$ of PSPB) that was replicated within each PSPB assay.

\section{Analysis of ISG15}

Total RNA was extracted from blood leukocytes using the Tempus Spin RNA Isolation Kit (Applied Biosystems, Foster City, CA) per the manufacturer's instructions (http://tools.thermofisher.com/content/sfs/ manuals/4382075b.pdf), including the optional DNase step. Extracted RNA $(1 \mu \mathrm{g})$ was reverse transcribed to cDNA (Bio-Rad iScript Reverse Transcription Supermix no. 1708840; Bio-Rad, Hercules, CA). Quantitative real-time PCR was conducted with the CFX96 Touch Real-Time PCR Detection System (Bio-Rad). Reaction mixtures and cycling conditions were performed as described elsewhere (Carvalho et al., 2017). Amplification efficiencies of primers were accepted within a range of 95 to $105 \%$ efficiency, and primer specificity was assessed by the presence of a single temperature dissociation peak. Cyclophilin-A (CycloA; NM_178320; forward: 5'-CACCGTGTTCTTCGACATCG-3'; reverse: 5'-ACAGCTCAAAAGAGACGCGG-3') was used as a housekeeping gene, and all samples were analyzed for ISG15 (NM_174366; forward: 5'-GGTATGAGCTGAAGCAGTT-3'; reverse: 5'-ACCTCCCTGCTGTCAAGGT-3'). Analysis was conducted using the $2^{-\Delta \Delta \mathrm{Ct}}$ method (Livak and Schmittgen, 2001). Blood samples collected $4 \mathrm{~d}$ after TAI served as a reference to calculate fold-change in ISG15 mRNA expression 18 and $20 \mathrm{~d}$ after TAI.

\section{Statistical Analyses}

The experiment was conducted as a completely randomized design, and cows were randomly assigned to treatments. All statistical analyses were performed using SAS computational software version 9.4 (SAS Institute Inc., Cary, NC). Analyses of binary response data [pregnancies per AI (P/AI), pregnancy loss, number of ovulations, and twins] were performed by logistic regression using the GLIMMIX procedure of SAS. The model included the fixed effects of treatment and double ovulation. Incidence of double ovulation was also analyzed by logistic regression with a model containing the fixed effect of treatment.

Continuous variables, including concentrations of P4 and PSPB, CL volume, and ovulatory follicle size, were analyzed by ANOVA using the MIXED procedure of SAS. The initial model included the fixed effect of treatment, time, double ovulation (only for P4 after TAI), and their interaction. Due to repeated measures within each cow, a repeated statement was used to account for autocorrelations by modeling the spatial power between sequential measurements. For P4 concentrations from -10 to $-1 \mathrm{~d}$, the model contained the fixed effect of treatment, time, and their interaction. For P4 concentrations from 1 to $15 \mathrm{~d}$, the model contained the fixed effect of treatment, time, double ovulation, and the interaction between time and double ovulation. For P4 concentrations between 18 and $67 \mathrm{~d}$ after TAI, only cows that maintained pregnancy were included and the model included the fixed effects of treatment and time. Progesterone concentrations were also compared between 15 and $32 \mathrm{~d}$ after TAI between pregnant cows and open cows with low and high PSPB $27 \mathrm{~d}$ after TAI. The model contained the fixed effect of pregnancy status and time. For PSPB concentrations in pregnant cows, the model contained the fixed effect of treatment, time, and pregnancy type (twins vs. singleton). Fold-change in ISG15 mRNA from 4 to 18 or $20 \mathrm{~d}$ after TAI was analyzed by ANOVA using the MIXED procedure of SAS. The model contained the fixed effects treatment, pregnancy status $32 \mathrm{~d}$ after TAI (pregnant vs. open), and double ovulation. In a secondary analysis, pregnant cows were subdivided into 3 groups based on ovulatory response and pregnancy type: (1) single ovulation with a singleton pregnancy, (2) double ovulation with a singleton pregnancy, and (3) double ovulation with a twin pregnancy. In addition, cows diagnosed not pregnant $32 \mathrm{~d}$ after TAI were subdivided into 2 groups based on PSPB concentrations $27 \mathrm{~d}$ after 
TAI. A receiver operating characteristic curve was generated with the LOGISTIC procedure of SAS using the outcome of pregnancy status at $32 \mathrm{~d}$ after TAI. The threshold of $0.77 \mathrm{ng} / \mathrm{mL}$ of PSBP was selected as a PSPB cutoff because it resulted in the highest Youden's $\mathrm{J}$ statistic (area under the curve $=0.929$, sensitivity $=1.0$, and specificity $=0.80)$. Thus, the analysis was based on 2 groups of cows: nonpregnant cows with low PSPB concentrations $27 \mathrm{~d}$ after TAI and nonpregnant cows with high PSPB concentrations $27 \mathrm{~d}$ after TAI. The correlation between follicle diameter before TAI and CL volume after TAI was determined using the CORR procedure of SAS.

A significant difference between levels of a classification variable was considered when $P \leq 0.05$, whereas differences between $P>0.05$ and $P \leq 0.10$ were considered a statistical tendency. Data are presented as least squares means \pm standard error of the means obtained from the MIXED procedure of SAS.

\section{RESULTS AND DISCUSSION}

The objective of this experiment was to revisit the hypotheses tested by Fricke et al. (2016) in moderateproducing Holstein-Friesian dairy cows managed in a seasonal-calving pasture-based system in Ireland, but in high-producing Holstein cows typical of confinementbased dairy systems in North America. To test our hypotheses related to the effect of $\mathrm{P} 4$ during growth of a synchronized follicular wave, we used a DoubleOvsynch protocol for first TAI as described by Souza et al. (2008) with several modifications as described by Fricke et al. (2016), which included an increased dose of GnRH at G1 (i.e., $200 \mu \mathrm{g}$ ) to increase ovulatory response to G1 (Giordano et al., 2013) as well as a second $\mathrm{PGF}_{2 \alpha}$ treatment administered $24 \mathrm{~h}$ after the first during the Breeding-Ovsynch portion of the Double-Ovsynch protocol to induce complete luteal regression by G2 (Brusveen et al., 2009; Carvalho et al., 2018). We further modified the protocols described by Fricke et al. (2016) in the present experiment by including exogenous $\mathrm{P} 4$ provided through intravaginal $\mathrm{P} 4$ inserts (i.e., CIDR inserts). Because almost one-third of the cows in the low-P4 treatment described by Fricke et al. (2016) expressed estrus before G2 and therefore failed to synchronize properly, low-P4 cows received a once-used CIDR insert for $7 \mathrm{~d}$ during the protocol (Figure 1) to suppress early expression of estrus, thereby increasing synchrony of cows subjected to low P4 during the synchronized follicular wave. Further, because high-producing dairy cows have decreased circulating $\mathrm{P} 4$ concentrations due to hepatic metabolism of $\mathrm{P} 4$ as a result of high feed intake, thereby increasing hepatic blood flow (Sangsritavong et al., 2002; Vasconcelos et al., 2003), high-P4 cows received 2 new CIDR inserts for $7 \mathrm{~d}$ during the protocol to achieve high circulating P4 concentrations during growth of the synchronized follicular wave (Figure 1). Supplementation with 2 CIDR inserts increased $\mathrm{P} 4$ in plasma by an additional $1.85 \mathrm{ng} / \mathrm{mL}$ compared with controls, resulting in concentrations of $2.77 \mathrm{ng} / \mathrm{mL}$ during development of the ovulatory follicle, which restored fertility in dairy cows lacking CL to a level similar to that of cows in diestrus (Bisinotto et al., 2015). These modifications allowed us to test our hypotheses related to low versus high $\mathrm{P} 4$ during growth of a synchronized follicular wave before TAI under experimental protocols in high-producing Holstein cows that allowed for a high rate of synchrony.

\section{Milk Production and BCS}

Average milk yield during the first 4 mo after calving did not differ $(P=0.74)$ between treatments and was $51.7 \pm 0.8$ and $52.0 \pm 0.8 \mathrm{~kg} / \mathrm{d}$ for high-P4 and low-P4 cows, respectively. For comparative purposes, milk production of multiparous cows in the present experiment was more than twice that of the primiparous and multiparous Holstein-Friesian cows managed in a seasonal-calving pasture-based system (24.7 vs. 24.9 $\mathrm{kg} / \mathrm{d}$ for high-P4 vs. low-P4 cows, respectively) at a similar stage of lactation (Fricke et al., 2016). On the day of enrollment, BCS did not differ $(P=0.82)$ between treatments (2.76 vs. 2.75 for high-P 4 vs. low-P4 cows, respectively), and BCS in the present study was similar to that of Holstein-Friesian cows reported by Fricke et al. (2016). The proportion of cows with BCS $\leq 2.5$ did not differ $(P=0.81)$ between treatments [33\% $(13 / 40)$ vs. $35 \%$ (14/40) for high-P4 vs. low-P4 cows, respectively].

\section{Effect of Treatment on Ovarian Structures}

To manipulate cows into a high-P4 environment during growth of the preovulatory follicle, we used a Double-Ovsynch protocol as described by Fricke et al. (2016) including the modifications described above. Ideally, cows that ovulate a follicle to the last $\mathrm{GnRH}$ treatment of the Pre-Ovsynch portion and G1 should have $2 \mathrm{CL}$ at the first $\mathrm{PGF}_{2 \alpha}$ treatment of the BreedingOvsynch portion of the Double-Ovsynch protocol. This then creates a high-P4 environment during growth of a synchronized follicular wave. To further increase P4 during growth of the preovulatory follicle for high-P4 cows, we included 2 new CIDR inserts to achieve a high-P4 environment. To manipulate cows into a low-P4 environment during growth of the preovulatory follicle, we administered a luteolytic dose of $\mathrm{PGF}_{2 \alpha} 24 \mathrm{~h}$ after G1. Because the early CL is refractory to $\mathrm{PGF}_{2 \alpha}$-induced 
Table 1. Effect (mean \pm SEM unless otherwise noted) of treatment on number and size of corpus luteum (CL) at the first $\mathrm{PGF}_{2 \alpha}$ treatment of the Breeding-Ovsynch portion of the Double-Ovsynch protocol, number and size of ovulatory follicles at the last GnRH treatment of the Breeding-Ovsynch portion of the Double-Ovsynch protocol (G2), incidence of double ovulation after G2, and CL volume $7 \mathrm{~d}$ after timed AI (TAI) in multiparous Holstein cows manipulated to have high versus low progesterone (P4) during growth of a synchronized follicular wave before TAI

\begin{tabular}{|c|c|c|c|}
\hline \multirow[b]{2}{*}{ Item } & \multicolumn{2}{|c|}{ Treatment $^{1}$} & \multirow[b]{2}{*}{$P$-value } \\
\hline & High P4 & Low $\mathrm{P} 4$ & \\
\hline CL at $\mathrm{PGF}_{2 \alpha}$ & $1.9 \pm 0.1$ & $1.2 \pm 0.1$ & $<0.01$ \\
\hline Ovulatory follicles at G2 & $1.2 \pm 0.1$ & $1.4 \pm 0.1$ & 0.01 \\
\hline Ovulatory follicle size at G2 & $14.8 \pm 0.3$ & $16.4 \pm 0.5$ & $<0.01$ \\
\hline Double ovulation $(\%$, no. $/$ no. $)$ & $10(4 / 40)$ & $33(13 / 40)$ & $<0.01$ \\
\hline CL volume $6 \mathrm{~d}$ after TAI $\left(\mathrm{mm}^{3}\right)$ & $5,550 \pm 341$ & $8,129 \pm 637$ & $<0.01$ \\
\hline
\end{tabular}

${ }^{1}$ Cows were submitted to a Double-Ovsynch protocol for synchronization of ovulation to receive first TAI. One day after G1, cows were randomly assigned to receive 2 new controlled internal drug-release (CIDR) inserts (high P4) or a PGF treatment and a used CIDR insert (low P4).

luteolysis until about $7 \mathrm{~d}$ after ovulation (Nascimento et al., 2014), a CL induced by the last GnRH treatment of the Pre-Ovsynch portion should regress, whereas the newly forming CL induced by G1 administered $24 \mathrm{~h}$ before this $\mathrm{PGF}_{2 \alpha}$ treatment should not (Nascimento et al., 2014). As expected, number of CL in the present experiment was greater $(P<0.01)$ for high-P4 cows than for low-P4 cows at the time of the first $\mathrm{PGF}_{2 \alpha}$ treatment during the Breeding-Ovsynch portion of the Double-Ovsynch protocol (Table 1), demonstrating that the experimental protocols successfully manipulated CL number during growth of the synchronized follicular wave.

One of our hypotheses was that low-P4 cows would ovulate larger follicles. Progesterone affects growth of a dominant follicle through a negative feedback on $\mathrm{LH}$ pulses from the anterior pituitary in which low $\mathrm{P} 4$ is associated with dramatically increased LH pulse frequency and amplitude (Kinder et al., 1996). Exposure of dominant follicles to increased LH pulses during growth of a dominant follicle before ovulation results in ovulation of a larger follicle (i.e., a persistent follicle; Ahmad et al., 1995), which in turn produces a larger CL after ovulation that produces more P4 (Vasconcelos et al., 2001). In agreement with our hypothesis, mean ovulatory follicle size in the present experiment was $1.6 \mathrm{~mm}$ greater $(P<0.01)$ for low-P4 cows than for high-P4 cows (Table 1). This increase in ovulatory follicle size resulted in an average CL volume $6 \mathrm{~d}$ after AI that was $2,579 \mathrm{~mm}^{3}$ greater for low-P4 cows than for high-P4 cows (Table 1). Overall, as size of the ovulatory follicle increased, CL volume $6 \mathrm{~d}$ after TAI also increased $(\mathrm{r}=0.60 ; P<0.01)$.

Another hypothesis in the present study was that high-producing Holstein cows subjected to a low-P4 environment during growth of a synchronized follicular wave would have an increased incidence of double ovulation. Low P4 during growth of ovulatory follicles in high-producing cows is associated with an increased incidence of double ovulation (Wiltbank et al., 2000). Further, cows in which the preovulatory follicle develops in the absence of $\mathrm{P} 4$ from a CL have a greater incidence of codominant follicles, resulting in double ovulations (Stevenson et al., 2007; Hayashi et al., 2008), likely due to increased LH pulses that result from the low-P4 environment that occur during selection of the dominant follicle from the cohort of growing follicles in the follicular wave (Lopez et al., 2005b). In the present experiment, low-P4 cows had more $(P=0.01)$ preovulatory follicles at G2 than high-P4 cows (Table 1), and the proportion of cows that double ovulated after G2 was 3 -fold greater $(P<0.01)$ for low-P4 cows than for high-P4 cows (Table 1).

Low P4 concentrations at the first GnRH treatment of an Ovsynch protocol that included a second $\mathrm{PGF}_{2 \alpha}$ treatment given $24 \mathrm{~h}$ after the first to complete luteal regression dramatically increased the incidence of double ovulation and subsequent pregnancy loss in high-producing Holstein cows (Martins et al., 2018). Despite the high circulating P4 concentrations in the high-P4 cows in the present experiment, $10 \%$ of the cows still double ovulated. Similar to the present study, $12 \%$ of cows manipulated to have high $\mathrm{P} 4$ throughout a synchronized follicular wave double ovulated (Martins et al., 2018). Thus, the subgroup of cows that double ovulated in these 2 experiments despite high $\mathrm{P} 4$ during growth of a synchronized follicular wave likely did so for reasons independent of circulating P4 concentrations. Although the incidence of double ovulation in low-P4 cows in the present study was only $33 \%$ compared with the $49 \%$ incidence of double ovulation in the low-P4 cows reported by Martins et al. (2018), both studies agree from a physiologic perspective that low P4 during growth of a synchronized follicular wave in 
high-producing dairy cows dramatically increases the incidence of double ovulation. By contrast, only 2 (1 cow in each treatment) of the moderate-producing Holstein-Friesian cows managed under a seasonal-calving pasture-based system had double ovulations (Fricke et al., 2016). The incidence of double ovulation is a sensitive endpoint affected by circulating $\mathrm{P} 4$ during growth of a follicular wave, and the lack of double ovulations in the study by Fricke et al. (2016) in moderate-producing Holstein-Friesian cows that were manipulated into a low-P4 environment is intriguing as well as difficult to explain physiologically.

\section{P4 Before TAI}

Similar to the study by Fricke et al. (2016), which used a similar experimental model, the treatments imposed in the present experiment successfully manipulated cows into divergent low-P4 and high-P4 environments during growth of the synchronized follicular wave before ovulation (Figure 2, upper left panel). On d -10 , $\mathrm{P} 4$ concentrations did not differ $(P=0.18)$ between treatments $(2.8 \pm 0.4$ vs. $2.2 \pm 0.3 \mathrm{ng} / \mathrm{mL}$ for high-P4 vs. low-P4 cows, respectively). By contrast, from 3 to 8 $\mathrm{d}$ before TAI, P4 concentrations were about $5 \mathrm{ng} / \mathrm{mL}$ greater $(P<0.01)$ for high-P4 cows than for low-P4 cows $(6.5 \pm 0.2$ vs. $1.7 \pm 0.1 \mathrm{ng} / \mathrm{mL}$, respectively). After induction of luteolysis during the protocol, P4 concentrations did not differ $(P=0.88)$ between treatments $(0.04 \pm 0.01$ vs. $0.1 \pm 0.1$ for high-P4 cows vs. low-P4 cows, respectively) $1 \mathrm{~d}$ before TAI. Thus, complete luteal regression for cows in both treatments occurred by G2 based on a P4 cutoff of $<0.4 \mathrm{ng} / \mathrm{mL}$ used in other experiments (Brusveen et al., 2009; Giordano et al., 2013; Carvalho et al., 2018). Further, inclusion of CIDR inserts during the protocols prevented cows from displaying estrus and failing to synchronize before scheduled TAI as reported by Fricke et al. (2016).

\section{P4 After TAI}

Ovulation of a larger follicle forms a larger CL that results in greater concentrations of circulating P4 after ovulation (Vasconcelos et al., 2001; Fricke et al., 2016). Concentrations of $\mathrm{P} 4$ in the present study increased $(P$ $<0.01)$ over time for both treatments. Concentrations of $\mathrm{P} 4$ at 1 and $4 \mathrm{~d}$ after TAI were $0.04 \pm 0.0$ and $0.6 \pm$ $0.05 \mathrm{ng} / \mathrm{mL}$, respectively, and did not differ $(P>0.1)$ between treatments (Figure 2, upper right panel); however, from 6 to $15 \mathrm{~d}$ after TAI, P4 concentrations were greater $(P<0.01)$ for low-P4 cows than for high-P4 cows (Figure 2, upper right panel). In addition, cows with double ovulations had greater P4 concentrations than cows with single ovulations $(4.0 \pm 0.3$ vs. $2.6 \pm$
$0.1 \mathrm{ng} / \mathrm{mL}$, respectively) due to the presence of $2 \mathrm{CL}$. For cows that maintained pregnancy until $67 \mathrm{~d}$ after TAI, P4 concentrations tended to be greater $(P=0.06)$ for low-P4 cows than for high-P4 cows (Figure 2, lower right panel). Furthermore, P4 concentrations were greater from 32 to $67 \mathrm{~d}$ after TAI than from 18 to $29 \mathrm{~d}$ after TAI (Figure 2, lower right panel).

Lactating dairy cows experience high rates of pregnancy loss before pregnancy status is diagnosed $32 \mathrm{~d}$ after AI. For example, at least half of the nonpregnant cows that maintained their CL until $32 \mathrm{~d}$ after TAI but were diagnosed not pregnant using transrectal ultrasonography were initially pregnant but underwent early pregnancy loss based on increased plasma PAG levels at 25 and $32 \mathrm{~d}$ after TAI (Ricci et al., 2017). To evaluate early pregnancy loss in the present study, a receiver operating characteristic curve was generated to determine a PSPB cutoff threshold to determine pregnancy status based on pregnancy outcomes determined using transrectal ultrasonography $32 \mathrm{~d}$ after TAI. Based on a threshold of $0.77 \mathrm{ng} / \mathrm{mL}$ PSBP, we divided cows into 3 subgroups according to their pregnancy status: (1) cows diagnosed pregnant based on transrectal ultrasonography 32 d after TAI, (2) cows diagnosed not pregnant based on transrectal ultrasonography that had high (>0.77 ng/mL) PSPB concentrations $27 \mathrm{~d}$ after TAI, and (3) cows diagnosed not pregnant based on transrectal ultrasonography that had low $(<0.77 \mathrm{ng} / \mathrm{mL})$ PSPB concentrations $27 \mathrm{~d}$ after TAI. For cows diagnosed pregnant $32 \mathrm{~d}$ after TAI, P4 concentrations remained constant over time and did not differ $(P>0.10)$ from those of cows diagnosed not pregnant with high PSPB concentrations, which also remained constant over time (Figure 2, lower left panel). By contrast, P4 concentrations for cows diagnosed not pregnant with low PSPB concentrations $27 \mathrm{~d}$ after TAI began to decrease $18 \mathrm{~d}$ after TAI and remained lower than for cows diagnosed not pregnant with high PSPB concentrations $27 \mathrm{~d}$ after TAI or for cows diagnosed pregnant (Figure 2, lower left panel). Thus, some cows are pregnant long enough to initiate maternal recognition of pregnancy by preventing luteolysis but subsequently undergo early pregnancy loss. These results agree with the observation that cows have high rates of pregnancy loss that can be determined based on extended luteal phases and the presence of circulating PAG concentrations such as PSPB before establishing pregnancy status using transrectal ultrasonography (Ricci et al., 2017).

\section{Effect of Treatment, Ovulation Number, and Pregnancy Type on ISG15 mRNA Expression}

The bovine blastocyst initiates the production and release of IFN $\tau$ to prevent secretion of uterine $\mathrm{PGF}_{2 \alpha}$ 


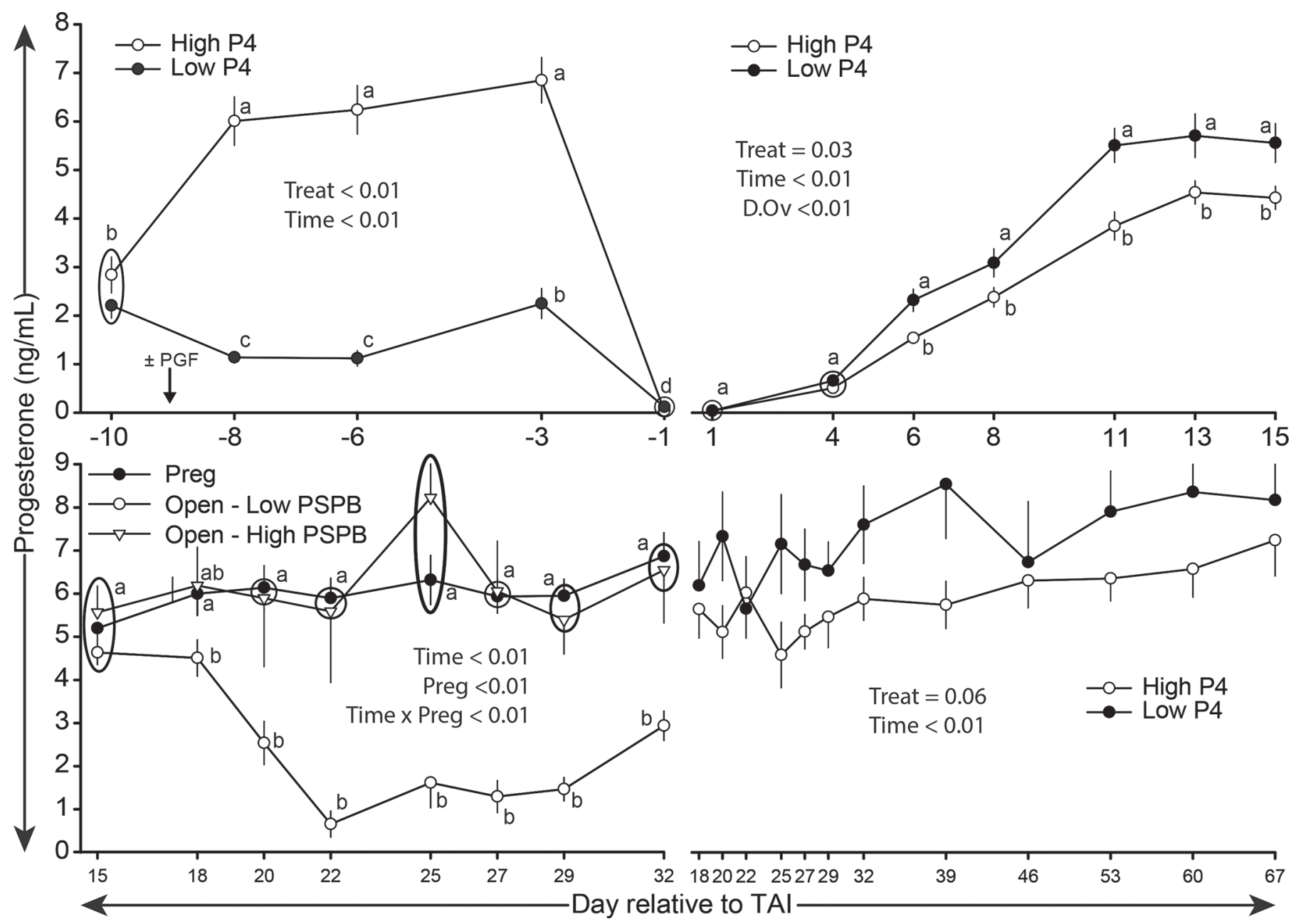

Figure 2. Mean \pm SEM serum progesterone (P4) concentrations in lactating multiparous Holstein cows. Effect of treatment (Treat) on serum P4 concentrations during the Breeding-Ovsynch portion of the Double-Ovsynch protocol (upper left panel). Effect of treatment on serum P4 concentrations after timed AI (TAI; upper right panel). Effect of pregnancy (Preg) status and low versus high pregnancy-specific protein B (PSPB) concentration $32 \mathrm{~d}$ after TAI on serum P4 concentrations from 15 to $32 \mathrm{~d}$ after TAI (lower left panel). Effect of treatment on serum P4 concentrations from 18 to $67 \mathrm{~d}$ after TAI for cows that maintained pregnancy until $67 \mathrm{~d}$ after TAI (lower right panel). Within a panel, means $( \pm$ SEM) with different letters $(\mathrm{a}-\mathrm{d})$ differ $(P<0.01)$. D.Ov $=$ double ovulation.

pulses, thereby preventing luteolysis and initiating maternal recognition of pregnancy (Spencer and Bazer, 2004). The production of IFN $\tau$ by the conceptus is detectable by d 7 in bovine blastocysts (Farin et al., 1990; Kubisch et al., 1998) and is then dramatically upregulated concomitant to blastocyst elongation (Mann and Lamming, 1999, 2001; Rizos et al., 2012) due to its role in the regulation of genes that affect implantation and conceptus growth (Spencer et al., 2007).

In the present study, we assessed the presence of IFN $\tau$ indirectly through detection of ISG15 (Han et al., 2006). We assessed the effect of both treatment and pregnancy status based on fold-change in ISG15 mRNA expression in blood leukocytes from baseline blood samples collected $4 \mathrm{~d}$ after TAI and that of blood samples collected 18 and $20 \mathrm{~d}$ after TAI. By $18 \mathrm{~d}$ after
TAI, pregnant cows had a 4.8 -fold increase $(P=0.05)$ in relative $I S G 15$ mRNA expression (Figure 3; upper panel); however, relative ISG15 mRNA expression did not differ between treatments $(P=0.23)$, and there was no treatment $\times$ pregnancy status interaction $(P$ $=0.45)$. Overall, cows with double ovulations had increased $(P<0.01)$ relative $I S G 15$ mRNA expression compared with cows with single ovulations. At $20 \mathrm{~d}$ after TAI, pregnant cows had an 8-fold increase $(P$ $<0.01$ ) in ISG15 mRNA expression (Figure 3, upper panel). Relative $I S G 15 \mathrm{mRNA}$ expression did not differ $(P=0.32)$ between treatments for pregnant or nonpregnant cows $20 \mathrm{~d}$ after TAI (Figure 3; upper panel); however, cows with double ovulations had greater $(P<$ 0.01 ) relative mRNA expression than cows with single ovulations. 


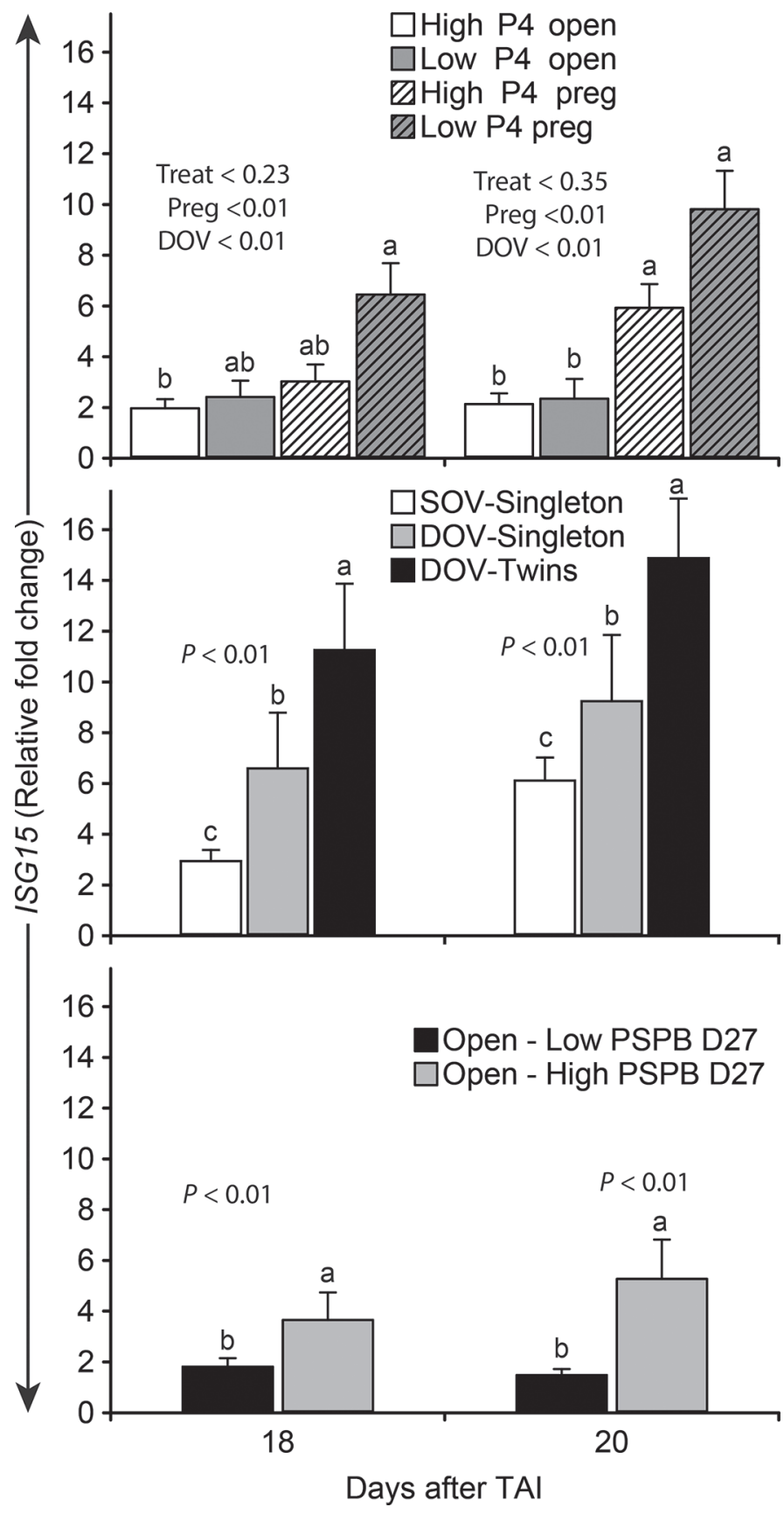

Figure 3. Mean \pm SEM relative fold change in IFN-stimulated gene 15 (ISG15) mRNA concentrations in blood leukocytes 18 and 20 d after timed AI (TAI) in lactating multiparous Holstein cows. Upper panel: effect of treatment (Treat) and pregnancy (Preg) status $32 \mathrm{~d}$ after TAI on ISG15. Middle panel: effect of ovulatory response (SOV $=$ single ovulation; $\mathrm{DOV}=$ double ovulation) and pregnancy type (singleton vs. twins) on ISG15. Bottom panel: effect of pregnancy status $27 \mathrm{~d}$ after TAI and low versus high serum pregnancy-specific protein B (PSPB) concentrations $27 \mathrm{~d}$ after TAI on ISG15. Within a day after TAI, means $( \pm$ SEM) with different superscripts $(\mathrm{a}-\mathrm{c})$ differ $(P<0.01) . \mathrm{P} 4=$ progesterone.
Because treatment also affected the incidence of double ovulation and the proportion of cows diagnosed with twin pregnancies, pregnant cows were further divided into 3 subgroups: (1) cows with a single ovulation after G2 and a singleton pregnancy $32 \mathrm{~d}$ after TAI, (2) cows with double ovulations after G2 and a singleton pregnancy $32 \mathrm{~d}$ after TAI, and (3) cows with double ovulations after G2 and a twin pregnancy $32 \mathrm{~d}$ after TAI (Figure 3, middle panel). At both $18(P<0.01)$ and $20(P<0.01) \mathrm{d}$ after TAI, relative $I S G 15 \mathrm{mRNA}$ expression was greatest $(P<0.01)$ for cows with double ovulations and a twin pregnancy, intermediate $(P<$ 0.01 ) for cows with double ovulations and a singleton pregnancy, and least $(P<0.01)$ for cows with single ovulations and a singleton pregnancy (Figure 3, middle panel). We are not aware of any studies that have reported ISG15 levels in cows with twin versus singleton pregnancies; however, it is likely that differences in ISG15 mRNA expression due to pregnancy type in the present experiment can be explained simply based on the number of conceptuses present during maternal recognition of pregnancy 18 and $20 \mathrm{~d}$ after TAI in each of these subgroups. In addition, circulating $\mathrm{P} 4$ has been positively associated with IFN $\tau$ synthesis in cattle (Kerbler et al., 1997), and the effect of treatment or increased incidence of double ovulations on circulating $\mathrm{P} 4$ during conceptus growth in the present study may also have affected ISG15 mRNA expression in the present study.

In a final analysis, nonpregnant cows were further divided based on the PSPB cutoff threshold defined previously $(0.77 \mathrm{ng} / \mathrm{mL})$. Thus, 2 subgroups of nonpregnant cows were analyzed: (1) nonpregnant cows with low $(<0.77 \mathrm{ng} / \mathrm{mL})$ PSPB concentrations $27 \mathrm{~d}$ after TAI and (2) nonpregnant cows with high $(>0.77$ $\mathrm{ng} / \mathrm{mL}$ ) PSPB concentrations $27 \mathrm{~d}$ after TAI. Nonpregnant cows with high PSPB concentrations $27 \mathrm{~d}$ after TAI had a 3.7- and 5.3- fold increase in relative ISG15 mRNA expression 18 and $20 \mathrm{~d}$ after TAI compared with nonpregnant cows with low PSPB concentrations $27 \mathrm{~d}$ after TAI (Figure 3, lower panel). Taken together with the analysis of low versus high PSPB concentrations on circulating P4 (Figure 2, lower left panel), it is clear that high-producing Holstein cows experience a high rate of early pregnancy loss before pregnancy status is normally assessed using transrectal ultrasonography based on an embryonic heartbeat $32 \mathrm{~d}$ after TAI.

\section{Effect of Treatment and Pregnancy Type on PSPB Concentrations}

Serum PSPB concentrations have been used as an indicator of pregnancy (Sasser et al., 1986) and to 
evaluate pregnancy loss (Giordano et al., 2012). Further, cows carrying twins have increased circulating PSPB, or PAG concentrations, or both early during pregnancy (López-Gatius et al., 2007; Giordano et al., 2012). Experimentally decreasing serum P4 after TAI in lactating Holstein cows decreased PSPB concentrations in pregnant cows by decreasing embryonic growth (Carvalho et al., 2017), whereas increasing P4 after TAI or in vitro fertilization embryo transfer in nulliparous Holstein heifers had no effect on PSPB concentrations during early pregnancy (Niles et al., 2019). By contrast, increasing serum P4 concentrations early after AI can advance embryonic growth by increasing expression of endometrial genes responsible for histotroph composition (Forde et al., 2009).

Serum PSPB concentrations were evaluated for cows that maintained pregnancies until $67 \mathrm{~d}$ after TAI and

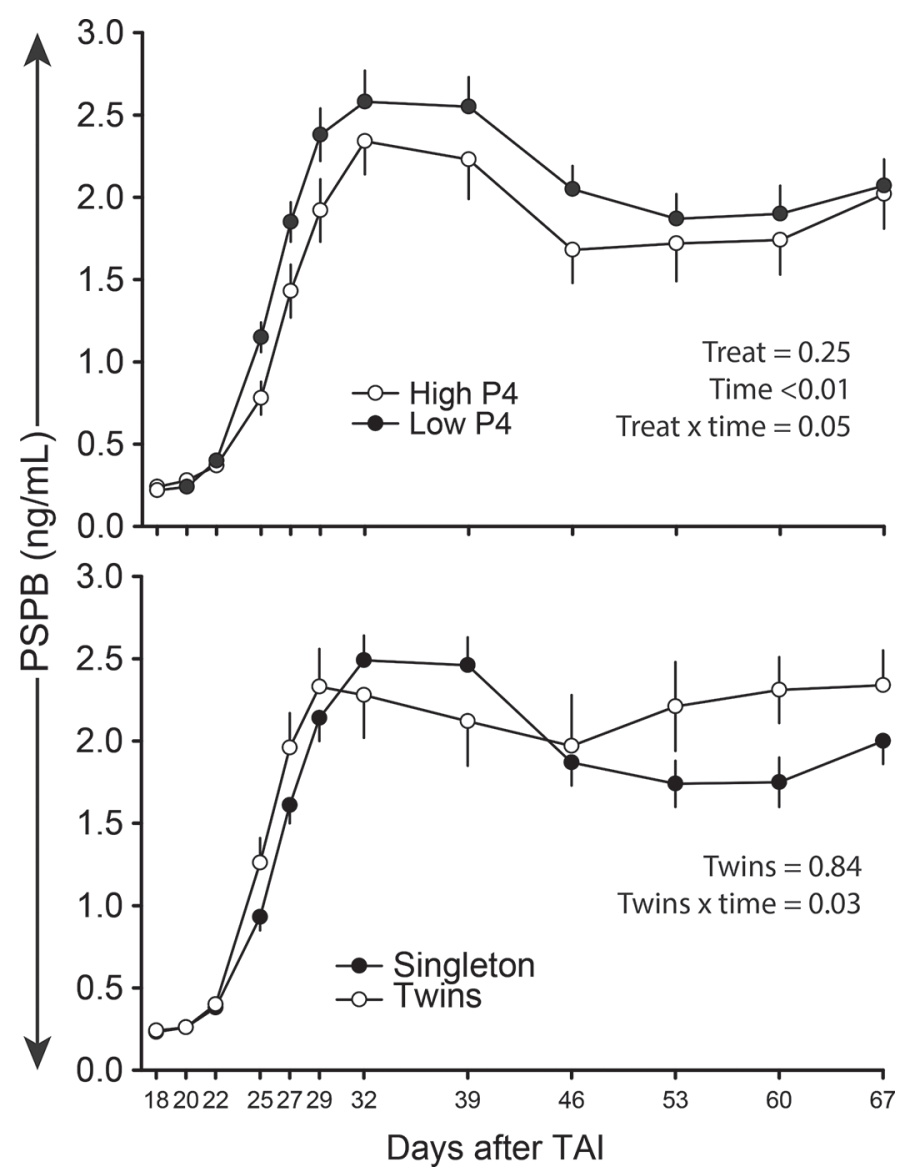

Figure 4. Mean \pm SEM serum pregnancy-specific protein B (PSPB) concentrations in lactating multiparous Holstein cows that maintained pregnancy until $67 \mathrm{~d}$ after timed AI (TAI). Upper panel: effect of treatment (Treat) on PSPB concentrations. Lower panel: effect of pregnancy type (singleton vs. twins) on PSPB concentrations. $\mathrm{P} 4=$ progesterone. are summarized in Figure 4. Overall, serum PSPB concentrations did not differ between treatments; however, a treatment $\times$ time interaction $(P=0.05)$ indicated that serum PSPB concentrations did not differ $(P>$ 0.10 ) between treatments between 18 and $22 \mathrm{~d}$ and between 53 and $67 \mathrm{~d}$ after TAI, whereas serum PSPB concentrations were greater $(P<0.01)$ for low-P4 cows than for high-P 4 cows between 25 and $46 \mathrm{~d}$ after TAI (Figure 4, upper panel).

Results from the present study with regard to serum PSPB concentrations are in contrast to those reported by Fricke et al. (2016) in which circulating PAG concentrations in Holstein-Friesian cows managed in a seasonal-calving pasture-based system in Ireland did not differ despite dramatic differences in $\mathrm{P} 4$ due to treatment both before and after TAI. In addition, PSPB concentrations in the present study did not differ $(P=0.88)$ between cows with singleton versus twin pregnancies; however, there was an interaction $(P=0.03)$ between number of conceptuses and time (Figure 4, lower panel). The comparison in circulating PSPB concentrations based on pregnancy type for cows that maintained pregnancies until $67 \mathrm{~d}$ after TAI in the present study should be interpreted with caution because of dramatic differences in embryo survival from an initial pregnancy diagnosis $32 \mathrm{~d}$ after TAI until 67 $\mathrm{d}$ after TAI between twin versus singleton pregnancies. By contrast, several studies have reported increased circulating PSPB concentrations, PAG concentrations, or both early during pregnancy for cows carrying twins versus singleton pregnancies (López-Gatius et al., 2007; Giordano et al., 2012).

\section{P/Al, Pregnancy Loss, and Twin Pregnancies}

At $32 \mathrm{~d}$ after TAI, $\mathrm{P} / \mathrm{AI}$ did not differ $(P=0.97)$ between treatments; however, cows with double ovulations had more $(P=0.02) \mathrm{P} / \mathrm{AI}$ than cows with single ovulations (Table 2). Further, neither treatment $(P$ $=0.49)$ nor number of ovulations $(P=0.11)$ affected pregnancy loss from 32 to $67 \mathrm{~d}$ after TAI (Table 2). Twinning in dairy cattle is an undesirable trait that reduces the overall profitability of a dairy operation through negative effects on cows calving twins as well as on calves born as twins (Fricke, 2001). The incidence of twin pregnancies in the present study was greater $(P<0.01)$ for low-P4 cows than for high-P 4 cows, and cows with double ovulations had a greater $(P<0.01)$ incidence of twin pregnancies than cows with single ovulations (Table 2 ).

We chose not to conduct this study as a field trial on a commercial dairy farm with a larger number of cows to assess the effect of treatment on $\mathrm{P} / \mathrm{AI}$ or pregnancy 
Table 2. Effect (\%; no./no. in parentheses) of treatment and ovulation response (single vs. double) on pregnancies per AI from 32 to 67 d after timed AI (TAI), pregnancy loss from 32 to $67 \mathrm{~d}$ after TAI, and twin pregnancies $32 \mathrm{~d}$ after TAI in multiparous Holstein cows

\begin{tabular}{|c|c|c|c|c|c|c|}
\hline \multirow[b]{2}{*}{ Item } & \multicolumn{2}{|c|}{ Treatment $^{1}$} & \multicolumn{2}{|c|}{ Ovulation } & \multicolumn{2}{|c|}{$P$-value } \\
\hline & High P4 & Low P4 & Single & Double & Treatment & Ovulation \\
\hline 32 & $45(18 / 40)$ & $53(21 / 40)$ & $41(26 / 63)$ & $77(13 / 17)$ & 0.97 & 0.02 \\
\hline 39 & $40(16 / 40)$ & $45(18 / 40)$ & $37(23 / 63)$ & $65(11 / 17)$ & 0.90 & 0.05 \\
\hline 46 & $38(15 / 40)$ & $40(17 / 40)$ & $37(23 / 63)$ & $47(8 / 17)$ & 0.99 & 0.45 \\
\hline 53 & $38(15 / 40)$ & $40(14 / 40)$ & $37(23 / 63)$ & $47(8 / 17)$ & 0.99 & 0.45 \\
\hline Pregnancy loss & $22(4 / 18)$ & $24(5 / 21)$ & $15(4 / 26)$ & $39(5 / 13)$ & 0.49 & 0.11 \\
\hline Twins & $0(0 / 17)$ & $29(6 / 31)$ & $0(0 / 26)$ & $46(6 / 13)$ & $<0.01$ & $<0.01$ \\
\hline
\end{tabular}

${ }^{1}$ Cows were submitted to a Double-Ovsynch protocol for synchronization of ovulation to receive first TAI. One day after G1, cows were randomly assigned to receive 2 new controlled internal drug-release (CIDR) inserts (high P4) or a PGF treatment and a used CIDR insert (low P4).

loss due to the potential of dramatically increasing twinning and pregnancy loss for cows manipulated to have low P4. Rather, we conducted an intensive study with frequent blood sampling and transrectal ultrasonography in our university research herd. Although the present study lacked statistical power to fully assess the effect of treatment on $\mathrm{P} / \mathrm{AI}$ and pregnancy loss, our results agree with a study in which cows were manipulated into a high- or low-P4 environment during growth of the ovulatory follicle (Martins et al., 2018). In that study, cows that were manipulated into a low-P4 environment during growth of the ovulatory follicle had a $49 \%$ incidence of double ovulation, $\mathrm{P} / \mathrm{AI}$ of $66.4 \%$, and pregnancy loss from d 23 to calving of $33 \%$ (Martins et al., 2018). Although cows with double ovulations have more $\mathrm{P} / \mathrm{AI}$ at the initial pregnancy diagnosis than cows with single ovulations (Fricke and Wiltbank, 1999; Martins et al., 2018), pregnancy loss from an initial pregnancy diagnosis to a pregnancy reconfirmation based on transrectal ultrasonography was 3 -fold greater for cows diagnosed with twins compared with cows diagnosed with singletons (Silva del Río et al., 2009). Pregnancy loss before $90 \mathrm{~d}$ in gestation was greater for cows with unilateral twins $(35 \%)$ than for cows with bilateral twins $(8 \%)$ in one experiment (López-Gatius and Hunter, 2005), and cows with unilateral double ovulations experienced greater pregnancy loss than cows with bilateral double ovulations (Martins et al., 2018). Taken together, these data support the idea that twinning due to double ovulations that results in unilateral twin pregnancies may be a significant cause of pregnancy loss in high-producing lactating dairy cows.

\section{CONCLUSIONS}

In agreement with our hypotheses, low P4 concentrations before TAI increased the incidence of double ovulation and twin pregnancies, serum PSPB concen- trations, and relative expression of ISG15 in blood leukocytes at 18 and $20 \mathrm{~d}$ after TAI in high-producing multiparous Holstein cows. Our results agree with and extend results from a study in which low P4 concentrations before TAI dramatically increased the incidence of double ovulation, P/AI, and the incidence of pregnancy loss, particularly for cows with unilateral double ovulations (Martins et al., 2018). Perhaps the most intriguing aspect of the present study is the contrast in reproductive outcomes from an earlier study that used a similar experimental model but was conducted using moderate-producing Holstein-Friesian cows managed in a seasonal-calving pasture-based system in Ireland (Fricke et al., 2016). The striking dichotomy in reproductive outcomes between these 2 experiments suggests that effects of genotype, milk production, hepatic steroid metabolism, or other factors independent of circulating P4 before or after TAI may play a physiologic role in controlling these reproductive outcomes. Finally, our results support the idea that manipulating high-producing multiparous Holstein cows into a high-P4 environment during a synchronized follicular wave before TAI can decrease the incidence of double ovulation and twinning. By contrast, high-producing multiparous Holstein cows in which a synchronized follicular wave occurs in a low-P4 environment before TAI have a dramatically increased incidence of double ovulation and twinning.

\section{ACKNOWLEDGMENTS}

We thank the University of Wisconsin-Madison dairy herd personnel at the Emmons Blaine Dairy Cattle Research Center in Arlington, Wisconsin, for their assistance with data collection and cow handling during the course of this experiment. This work was supported by the USDA National Institute of Food and Agriculture Hatch project 231440 to P. M. Fricke. 


\section{REFERENCES}

Ahmad, N., F. N. Schrick, R. L. Butcher, and E. K. Inskeep. 1995. Effect of persistent follicles on early embryonic losses in beef cows. Biol. Reprod. 52:1129-1135.

Bisinotto, R. S., L. O. Castro, M. B. Pansani, C. D. Narciso, N. Martinez, L. D. P. Sinedino, T. L. C. Pinto, N. S. Van de Burgwal, H. M. Bosman, R. S. Surjus, W. W. Thatcher, and J. E. P. Santos. 2015. Progesterone supplementation to lactating dairy cows without a corpus luteum at initiation of the Ovsynch protocol. J. Dairy Sci. 98:2515-2528.

Bisinotto, R. S., R. C. Chebel, and J. E. Santos. 2010. Follicular wave of the ovulatory follicle and not cyclic status influences fertility of dairy cows. J. Dairy Sci. 93:3578-3587.

Brusveen, D. J., A. H. Souza, and M. C. Wiltbank. 2009. Effects of additional prostaglandin $\mathrm{F}_{2 \alpha}$ and estradiol-17 $\beta$ during Ovsynch in lactating dairy cows. J. Dairy Sci. 92:1412-1422.

Carvalho, P. D., C. C. Consentini, S. R. Weaver, R. V. Barletta, L. L. Hernandez, and P. M. Fricke. 2017. Temporarily decreasing progesterone after timed artificial insemination decreased expression of interferon-tau stimulated gene 15 (ISG15) in blood leukocytes, serum PSPB concentrations, and embryo size in lactating Holstein cows. J. Dairy Sci. 100:3233-3242.

Carvalho, P. D., J. N. Guenther, M. J. Fuenzalida, M. C. Amundson, M. C. Wiltbank, and P. M. Fricke. 2014. Presynchronization using a modified Ovsynch protocol or a single gonadotropin-releasing hormone injection $7 \mathrm{~d}$ before an Ovsynch-56 protocol for submission of lactating dairy cows for first timed AI. J. Dairy Sci. 97:6305-6315.

Carvalho, P. D., V. G. Santos, J. O. Giordano, M. C. Wiltbank, and P. M. Fricke. 2018. Development of fertility programs to achieve high 21-day pregnancy rates in high-producing dairy cows. Theriogenology $114: 165-172$.

Farin, C. E., K. Imakawa, T. R. Hansen, J. J. McDonnell, C. N. Murphy, P. W. Farin, and R. M. Roberts. 1990. Expression of trophoblastic interferon genes in sheep and cattle. Biol. Reprod. 43:210-218.

Forde, N., F. Carter, T. Fair, M. A. Crowe, A. C. O. Evans, T. E. Spencer, F. W. Bazer, R. McBride, M. P. Boland, P. O'Gaora, P. Lonergan, and J. F. Roche. 2009. Progesterone-regulated changes in endometrial gene expression contribute to advanced conceptus development in cattle. Biol. Reprod. 81:784-794.

Fricke, P. M. 2001. Review: Twinning in dairy cattle. Prof. Anim. Sci. $17: 61-67$

Fricke, P. M., D. Z. Caraviello, K. A. Weigel, and M. L. Welle. 2003. Fertility of dairy cows after resynchronization of ovulation at three intervals following first timed insemination. J. Dairy Sci. 86:39413950.

Fricke, P. M., P. D. Carvalho, M. C. Lucy, F. Curran, M. M. Herlihy, S. M. Waters, J. A. Larkin, M. A. Crowe, and S. T. Butler. 2016. Effect of manipulating progesterone before timed artificial insemination on reproductive and endocrine parameters in seasonal-calving pasture-based Holstein-Friesian cows. J. Dairy Sci. 99:6780-6792.

Fricke, P. M., and M. C. Wiltbank. 1999. Effect of milk production on the incidence of double ovulation in dairy cows. Theriogenology $52: 1133-1143$.

Giordano, J. O., P. M. Fricke, S. Bas, R. Pawlisch, J. N. Guenther, A. B. Nascimento, and M. C. Wiltbank. 2013. Effect of increasing $\mathrm{GnRH}$ and $\mathrm{PGF}_{2 \alpha}$ dose during Double-Ovsynch on ovulatory response, luteal regression, and fertility of lactating dairy cows. Theriogenology 80:773-783.

Giordano, J. O., J. N. Guenther, G. Lopes Jr., and P. M. Fricke. 2012. Changes in serum pregnancy-associated glycoprotein, pregnancyspecific protein $\mathrm{B}$, and progesterone concentrations before and after induction of pregnancy loss in lactating dairy cows. J. Dairy Sci. 95:683-697.

Han, H., K. J. Austin, L. A. Rempel, and T. R. Hansen. 2006. Low blood ISG15 mRNA and progesterone levels are predictive of nonpregnant dairy cows. J. Endocrinol. 191:505-512.

Hayashi, K. G., M. Matsui, T. Shimizu, N. Sudo, A. Sato, K. Shirasuna, M. Tetsuka, K. Kida, D. Schams, and A. Miyamoto. 2008. The absence of corpus luteum formation alters the endocrine profile and affects follicular development during the first follicular wave in cattle. Reproduction 136:787-797.

Kerbler, T. L., M. M. Buhr, L. T. Jordan, K. E. Leslie, and J. S. Walton. 1997. Relationship between maternal plasma progesterone concentration and interferon-tau synthesis by the conceptus in cattle. Theriogenology 47:703-714.

Kinder, J. E., F. N. Kojima, E. G. M. Bergfeld, M. E. Wehrman, and K. E. Fike. 1996. Progestin and estrogen regulation of pulsatile LH release and development of persistent ovarian follicles in cattle. J. Anim. Sci. 74:1424-1440.

Kubisch, H. M., M. A. Larson, and R. M. Roberts. 1998. Relationship between age of blastocyst formation and interferon- $\tau$ secretion by in vitro-derived bovine embryos. Mol. Reprod. Dev. 49:254-260.

Livak, K. J., and T. D. Schmittgen. 2001. Analysis of relative gene expression data using real-time quantitative PCR and the $2-\Delta \Delta \mathrm{CT}$ method. Methods 25:402-408.

Lopez, H., D. Z. Caraviello, L. D. Satter, P. M. Fricke, and M. C. Wiltbank. 2005a. Relationship between level of milk production and multiple ovulations in lactating dairy cows. J. Dairy Sci. 88:2783-2793.

Lopez, H., R. Sartori, and M. C. Wiltbank. 2005b. Reproductive hormones and follicular growth during development of one or multiple dominant follicles in cattle. Biol. Reprod. 72:788-795.

López-Gatius, F., M. J. Garbayo, P. Santolaria, J. Yaniz, A. Ayad, N. M. de Sousa, and J. F. Beckers. 2007. Milk production correlates negatively with plasma levels of pregnancy-associated glycoprotein (PAG) during the early fetal period in high producing dairy cows with live fetuses. Domest. Anim. Endocrinol. 32:29-42.

López-Gatius, F., and R. H. F. Hunter. 2005. Spontaneous reduction of advanced twin embryos: Its occurrence and clinical relevance in dairy cattle. Theriogenology 63:118-125.

Mann, G. E., and G. E. Lamming. 1999. The influence of progesterone during early pregnancy in cattle. Reprod. Domest. Anim. $34: 269-274$

Mann, G. E., and G. E. Lamming. 2001. Relationship between maternal endocrine environment, early embryo development and inhibition of the luteolytic mechanism in cows. Reproduction 121:175180.

Martins, J. P. N., D. Wang, N. Mu, G. F. Rossi, A. P. Martini, V. R. Martins, and J. R. Pursley. 2018. Level of circulating concentrations of progesterone during ovulatory follicle development affects timing of pregnancy loss in lactating dairy cows. J. Dairy Sci. 101:10505-10525

Nascimento, A. B., A. H. Souza, A. Keskin, R. Sartori, and M. C. Wiltbank. 2014. Lack of complete regression of the Day 5 corpus luteum after one or two doses of $\mathrm{PGF}_{2 \alpha}$ in nonlactating Holstein cows. Theriogenology 81:389-395.

Niles, A. M., H. P. Fricke, P. D. Carvalho, M. C. Wiltbank, L. L. Hernandez, and P. M. Fricke. 2019. Effect of treatment with human chorionic gonadotropin 7 days after artificial insemination or at the time of embryo transfer on reproductive outcomes in nulliparous Holstein heifers. J. Dairy Sci. 102:2593-2606.

NRC. 2001. Nutrient Requirements of Dairy Cattle. 7th rev. ed. National Academies Press, Washington, DC

Ricci, A., P. D. Carvalho, M. C. Amundson, and P. M. Fricke. 2017. Characterization of luteal dynamics in lactating Holstein cows for 32 days after synchronization of ovulation and timed artificial insemination. J. Dairy Sci. 100:9851-9860.

Rizos, D., S. Scully, A. K. Kelly, A. D. Ealy, R. Moros, P. Duffy, A. Al Naib, N. Forde, and P. Lonergan. 2012. Effects of human chorionic gonadotrophin administration on Day 5 after oestrus on corpus luteum characteristics, circulating progesterone and conceptus elongation in cattle. Reprod. Fertil. Dev. 24:472-481.

Sangsritavong, S., D. K. Combs, R. Sartori, L. E. Armentano, and M C. Wiltbank. 2002. High feed intake increases liver blood flow and metabolism of progesterone and estradiol-17 $\beta$ in dairy cattle. J. Dairy Sci. 85:2831-2842.

Santos, J. E. P., W. W. Thatcher, R. C. Chebel, R. L. A. Cerri, and K. N. Galvão. 2004. The effect of embryonic death rates in cattle 
on the efficacy of estrus synchronization programs. Anim. Reprod. Sci. 82-83:513-535.

Sasser, R. G., C. A. Ruder, K. A. Ivani, J. E. Butler, and W. C. Hamilton. 1986. Detection of pregnancy by radioimmunoassay of a novel pregnancy-specific protein in serum of cows and a profile of serum concentration during gestation. Biol. Reprod. 35:936-942.

Silva del Río, N., J. Colloton, and P. M. Fricke. 2009. Factors affecting pregnancy loss for single and twin pregnancies in a high-producing dairy herd. Theriogenology 71:1462-1471.

Silva del Río, N., S. Stewart, P. Rapnicki, Y. M. Chang, and P. M. Fricke. 2007. An observational analysis of twin births, calf sex ratio, and calf mortality in Holstein dairy cattle. J. Dairy Sci. 90:1255-1264.

Souza, A. H., H. Ayres, R. M. Ferreira, and M. C. Wiltbank. 2008. A new presynchronization system (Double-Ovsynch) increases fertility at first postpartum timed AI in lactating dairy cows. Theriogenology 70:208-215.

Spencer, T. E., and F. W. Bazer. 2004. Conceptus signals for establishment and maintenance of pregnancy. Reprod. Biol. Endocrinol. $2: 49-63$.

Spencer, T. E., G. A. Johnson, F. W. Bazer, R. C. Burghardt, and M. Palmarini. 2007. Pregnancy recognition and conceptus implanta- tion in domestic ruminants: Roles of progesterone, interferons and endogenous retroviruses. Reprod. Fertil. Dev. 19:65-78.

Stevenson, J. S., M. A. Portaluppi, and D. E. Tenhouse. 2007. Factors influencing upfront single- and multiple-ovulation incidence, progesterone, and luteolysis before a timed insemination resynchronization protocol. J. Dairy Sci. 90:5542-5551.

Vasconcelos, J. L. M., S. Sangsritavong, S. J. Tsai, and M. C. Wiltbank. 2003. Acute reduction in serum progesterone concentrations after feed intake in dairy cows. Theriogenology 60:795-807.

Vasconcelos, J. L. M., R. Sartori, H. N. Oliveira, J. G. Guenther, and M. C. Wiltbank. 2001. Reduction in size of the ovulatory follicle reduces subsequent luteal size and pregnancy rate. Theriogenology $56: 307-314$

Wiltbank, M. C., G. M. Baez, A. Garcia-Guerra, M. Z. Toledo, P. L. J. Monteiro, L. F. Melo, J. C. Ochoa, J. E. P. Santos, and R. Sartori. 2016. Pivotal periods for pregnancy loss during the first trimester of gestation in lactating dairy cows. Theriogenology 86:239-253.

Wiltbank, M. C., P. M. Fricke, S. Sangritasvong, R. Sartori, and O. J. Ginther. 2000. Mechanisms that prevent and produce double ovulations in dairy cattle. J. Dairy Sci. 83:2998-3007. 